\title{
Effect of Treatment Time of 1-MCP on Ripening of 'Fuji' Apples Stored at Low and Room Temperature for a Long Period
}

\author{
Hyun-Sug Choi, Seok-Kyu Jung* \\ Department of Floriculture, St. Thomas Hall Building (D9), Catholic University of Daegu, Gyeongsan, Gyeongsangbuk-do 712-702, \\ Republic of Korea \\ *Corresponding author: gentleman71@msn.com
}

Received August 15, 2014; Revised August 30, 2014; Accepted September 09, 2014

\begin{abstract}
The effect of 1-methycyclopropene (1-MCP) treatment at 0, 2, and $4 \mathrm{~d}$ after harvest (0 DAH, 2 DAH, and 4 DAH) of apples [Malus sylvestris (L.) Mill var. domestica (Borkh.) Mansf.] was evaluated on several fruit quality parameters for $180-\mathrm{d}$ at $0.5^{\circ} \mathrm{C}$ in the air, followed by $28-\mathrm{d}$ at room temperature. The $1,000 \mathrm{nl} \mathrm{l}^{-1} 1$-MCP treatments were adequate to maintain fruit titratable acidity (TA) and firmness, inhibiting the rates of ethylene production and respiration during the storage of both cold and the room temperatures, regardless of the 1-MCP treatment time.
\end{abstract}

Keywords: apple, CO2, ethylene, fruit quality, 1-MCP

Cite This Article: Hyun-Sug Choi, and Seok-Kyu Jung, "Effect of Treatment Time of 1-MCP on Ripening of 'Fuji' Apples Stored at Low and Room Temperature for a Long Period.” Journal of Food and Nutrition Research, vol. 2, no. 9 (2014): 617-620. doi: 10.12691/jfnr-2-9-14.

\section{Introduction}

The 1-methylcyclopropene (1-MCP) has been used to retard ripening or senescence of climacteric apple fruit, binding to the sites of ethylene reception of the fruit for a while [1,2]. Loss of 1-MCP inhibition of ripening apple fruit was associated with softening and development of the physiological storage disorder $[1,2,3,4]$. Instant or delayed application of 1-MCP affected several attributers of postharvest apple fruit quality $[2,3,4,5,6,7,8]$ on various apple cultivars having different initial ethylene production from harvest, and reviewed by Watkins [2]. Apple growers or the distributers typically preserved fruits at low temperature without the application of 1-MCP or by delaying application of 1-MCP for several days from harvest until the consumers need the fruit on the market. This phenomenon has also not being observed for prolonged-cold storage, followed by room temperature storage, the latter which is the normal storage condition for a large number of apples in Korea. Little information is available about the responses of delayed 1-MCP treatment on fruit ripening of 'Fuji' apples during cold storage [6,8].

'Fuji' apples comprise approximately $64 \%$ of the total apple production area in 2007 [9], which ranks the first of the apple cultivars in Korea. The fruit is large-size and late-season cultivar (mid-October), with a storage life of between 30 - $50 \mathrm{~d}$ at room temperature or approx. 150-d in the air at $0.5^{\circ} \mathrm{C}$. 'Fuji' apples kept in the cold storage over six months declined their storability during the shelf life periods of $7 \mathrm{~d}$ at $20^{\circ} \mathrm{C}$, resulting in decreased marketability to the other Asian countries. Fruit quality of early 'Tsugaru' apple cultivar was compared with 1-MCP versus ethylene right after 1-MCP treatment in cold storage for long periods, followed by a shelf life period of a month [10], which has not been hitherto evaluated for a late season of apple cultivar, such as 'Fuji'.

The objective of this study was to investigate the responses of 1-MCP treatment time on the quality of 'Fuji' apples in the air at $0.5^{\circ} \mathrm{C}$ for six months and on subsequent fruit ripening for $28 \mathrm{~d}$ at $20^{\circ} \mathrm{C}$ in the room temperature.

\section{Materials and Methods}

\subsection{Plant Source and Sampling}

Fruits from mature 'Fuji' apple (Malus $\times$ domestica Borkh.) trees were harvested on the orchard farm at Kongju National University at Yesan, South Korea $\left(36^{\circ} \mathrm{N}\right.$, $\left.126^{\circ} \mathrm{E}\right)$. Any malformed fruit or injured fruit were excluded from the study, and the cleaned fruit were then cooled to $0^{\circ} \mathrm{C}$ for $12 \mathrm{~h}(85$ - 90\% RH). Experiment included the effects of treatment time of 1-MCP on the fruit quality and rates of ethylene production and respiration for the $180-\mathrm{d}$ cold storage at $0.5^{\circ} \mathrm{C}$. We then evaluated the fruit quality of the apples applied with those above treatments during the 28- $\mathrm{d}$ at $7 \mathrm{~d}$ intervals at room temperature $\left(20 \pm 2^{\circ} \mathrm{C}\right.$; $\left.80-85 \% \mathrm{RH}\right)$.

Ten individual 'Fuji' apple fruit per storage time were randomly removed from the storage to measure their 
soluble solid contents (SSC), titratable acidity (TA), and fruit firmness. The other ten individual fruit were taken to measure the rates of fruit ethylene and respiration.

\subsection{Treatment Condition}

1-MCP as a powder (SmartFresh ${ }^{\mathrm{SM}}$, AgroFresh, Spring House, PA, USA; $0.14 \%$ active ingredient by weight) was allowed to release a final gas concentration of $1,000 \mathrm{nl} \mathrm{l}^{-1}$ into the Erlenmeyer flasks. Fruit were pre-cooled overnight and were then either untreated (control) or treated with 1,000 $\mathrm{nl} \mathrm{l}^{-1} 1$-MCP $0 \mathrm{~d}, 2 \mathrm{~d}$, and $4 \mathrm{~d}$ after harvest (0 DAH, $2 \mathrm{DAH}$, and $4 \mathrm{DAH})$. The 1-MCP was supplied from the sealed 135 - $\mathrm{L}$ plastic containers at $10^{\circ} \mathrm{C}$ for $24 \mathrm{~h}$ and then ventilated at a rate of $30 \mathrm{ml} \mathrm{min}^{-1}$. 1MCP from the powder was liberated by adding water of it. Untreated-fruit were also applied from the same plastic containers used for 1-MCP-treated fruit under the same stored condition. All harvested fruit were then stored at $0.5^{\circ} \mathrm{C}$ in air for up to 6 months followed by room temperature for $28 \mathrm{~d}$, and some of fruit were taken out of the storage whenever the fruit needed to be investigated for ripening.

\subsection{Ethylene Production, $\mathrm{CO}_{2}$, and Fruit Quality}

The $1.0 \mathrm{ml}$ of internal headspace gas was extracted from the interior of each apple fruit in order to determine the ethylene and $\mathrm{CO}_{2}$ concentrations. Ethylene production in the fruit samples were analyzed using a gas chromatography (GC, Hewlett-Packard 5890 series II; Agilent Co., Wilmington, DE, USA), which was fitted with a stainless steel needle column packed with activated 60/80 mesh alumina F-1 ( $2 \mathrm{~m} \times 2 \mathrm{~mm}$, i.d.). The detection was via a flame ionization detector [11]. Each fruit was placed into a $1 \mathrm{~L}$ plastic container with an air flow rate of $30 \mathrm{ml} \mathrm{min}^{-1}$, and the containers were fitted with a septum, and the $1 \mathrm{ml}$ gas samples were withdrawn slowly from the apples at each measurable time point. The gas samples were then injected into the GC meter, and the quantified values obtained from the GC were calculated for the ethylene concentrations with the external standards. The $1.0 \mathrm{ml}$ of each headspace gas was also removed to measure its $\mathrm{CO}_{2}$ content using a GC (Varian 3400; Varian Inc., Santa Clara, CA, USA) equipped with a $2.4 \mathrm{~mm}$ (i.d.) $\times$ 2-m long column filled with 60/80-mesh active charcoal. $\mathrm{CO}_{2}$ concentrations were measured using a thermal conductivity detector at $110^{\circ} \mathrm{C}$, with a carrier gas of

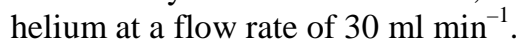

Soluble solid contents (SSC; ${ }^{\circ}$ Brix ) in flesh were measured with a hand-held digital refractometer (RA520N; Kyoto Electronic Co., Kyoto, Japan). For measurement of titratable acidity (TA), fruit juice of each sample was titrated with $0.1 \mathrm{~N}$-sodium hydroxide to an end point of pH 8.2 and converted to malic acid (\%). Fruit were assessed manually on the opposite paired sides of each apple using a TA-XT2 pressure tester (Stable Micro system Ltd., Godalming, England) fitted with a $5.0 \mathrm{~mm}$ cylindrical end probe for measuring flesh firmness $(\mathrm{N})$.

\subsection{Statistical Analysis}

The study was arranged in a completely randomized design with ten fruit replications of each treatment per storage time. All data were subjected to ANOVA using Minitab software v. 14.1 (Minitab, Inc., State College, PA, USA). Means were separated using Duncan's New Multiple Range Test at $P=0.05$. Data over time were also shown as means \pm standard errors.

\section{Results and Discussion}

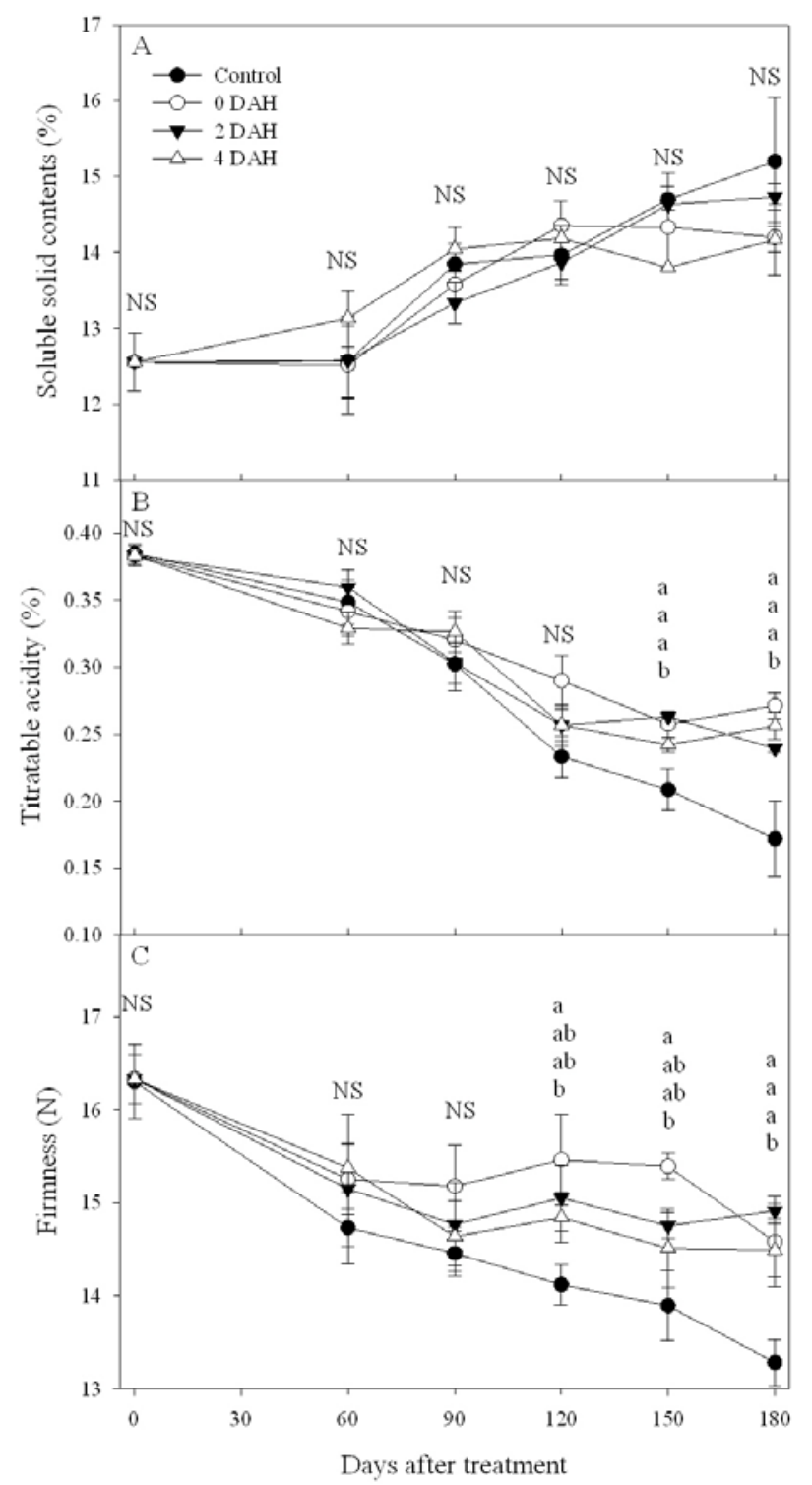

Figure 1. Soluble solid contents (SSC; A), titratable acidity (TA; B), and firmness (C) of 'Fuji' apple fruits untreated (control) or treated with $1,000 \mathrm{nl} \mathrm{l}^{-1} 1$-MCP of delays of 0,2 , and 4 days after harvest (DAH) in $0.5^{\circ} \mathrm{C}$ cold storage for $180 \mathrm{~d}$ after treatment. Bars represent error of the means (S.E.M; $n=10$ ), when larger than the dimension of the symbol. Different lower-case letters adjacent to each datum point at each sampling date indicate differences as determined by Duncan's MRT ( $P \leq$ $0.05)$

Fruit SSC increased during the 180 -d cold storage at control or 1-MCP treatments, presumably due to the conversion of starch to sugars [12]. The SSC were not affected by time of 1-MCP treatment (Figure 1A) as summarized from several reports for most apple cultivars [13]. Fruit SSC and TA in the long storage type apples, such as 'Fuji', were not affected by 1-MCP until 3 months cold storage [1]. However, fruit TA decreased during the storage time, and the control fruit had lower TA content 
from 150-d storage compared with those of 1-MCPtreated fruits (Figure 1B) as observed in other 'Fuji' apples 6 . Flesh firmness in control fruit decreased rapidly during the storage (Figure 1C), and the difference between the control and 1-MCP was significant with advanced storage time, which was agreement with other observations on different apple cultivars [14]. Time of 1MCP treatment did not affect fruit firmness during the storage.

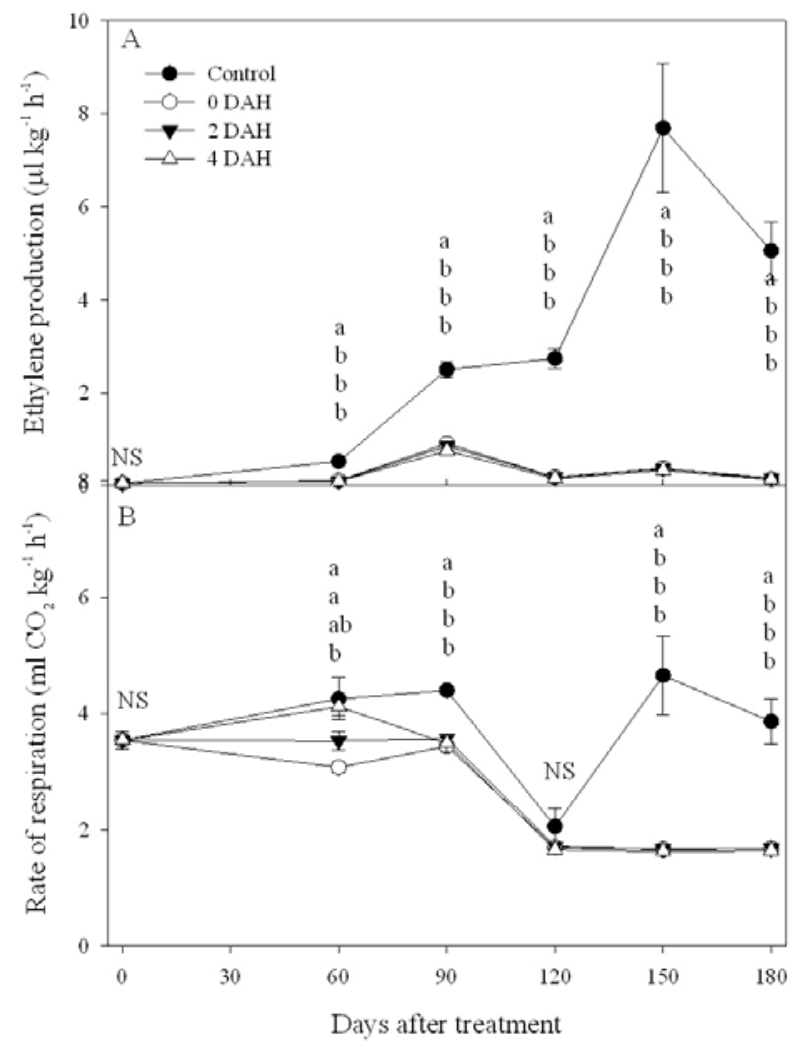

Figure 2. Rates of ethylene production (A) and respiration (B) of 'Fuji' apple fruits untreated (control) or treated with $1,000 \mathrm{nl} \mathrm{l}^{-1} 1$-MCP of delays of 0,2 , and 4 days after harvest (DAH) in $0.5^{\circ} \mathrm{C}$ cold storage for $180 \mathrm{~d}$ after treatment. Bars represent error of the means (S.E.M; $\mathrm{n}=10$ ), when larger than the dimension of the symbol. Different lower-case letters adjacent to each datum point at each sampling date indicate differences as determined by Duncan's MRT $(\mathrm{P} \leq 0.05)$

Control fruit had higher rates of ethylene production and fruit respiration rate than those of 1-MCP-treated fruits during the storage (Figure 2), with not being observed for the significant difference of the above variables from time of 1-MCP-treatment. Apple fruit is considered as a climacteric fruit, rapidly increasing rates of ethylene production and respiration after the onset of climacteric phase with increasing storage periods [15]. Less delay of tomato ripening by 1-MCP was associated with higher ethylene concentration in the fruit at the time of treatment $[14,16]$. Responses of apple cultivar to 1MCP treatment widely varied due to the different binding ability to ethylene receptor sites $[12,14,17]$. On the other hand, the 1,000 $\mathrm{nl} \mathrm{l}^{-1}$ 1-MCP application, the maximum allowed concentration in USA, between 3 - 7 DAH was effective in saturating the 1-MCP response for most apple cultivars [1]. Four days of delayed 1-MCP treatment were sufficient to maintain low level of ethylene concentration in 'Fuji' apples. This was well documented for 1-MCPtreated 'Cortland' and 'Low Rome' apples within 7 DAH in air at $0.5^{\circ} \mathrm{C}$ for six months but was not observed after that for fruit associating with the development of fruit softening and senescence breakdown [4].

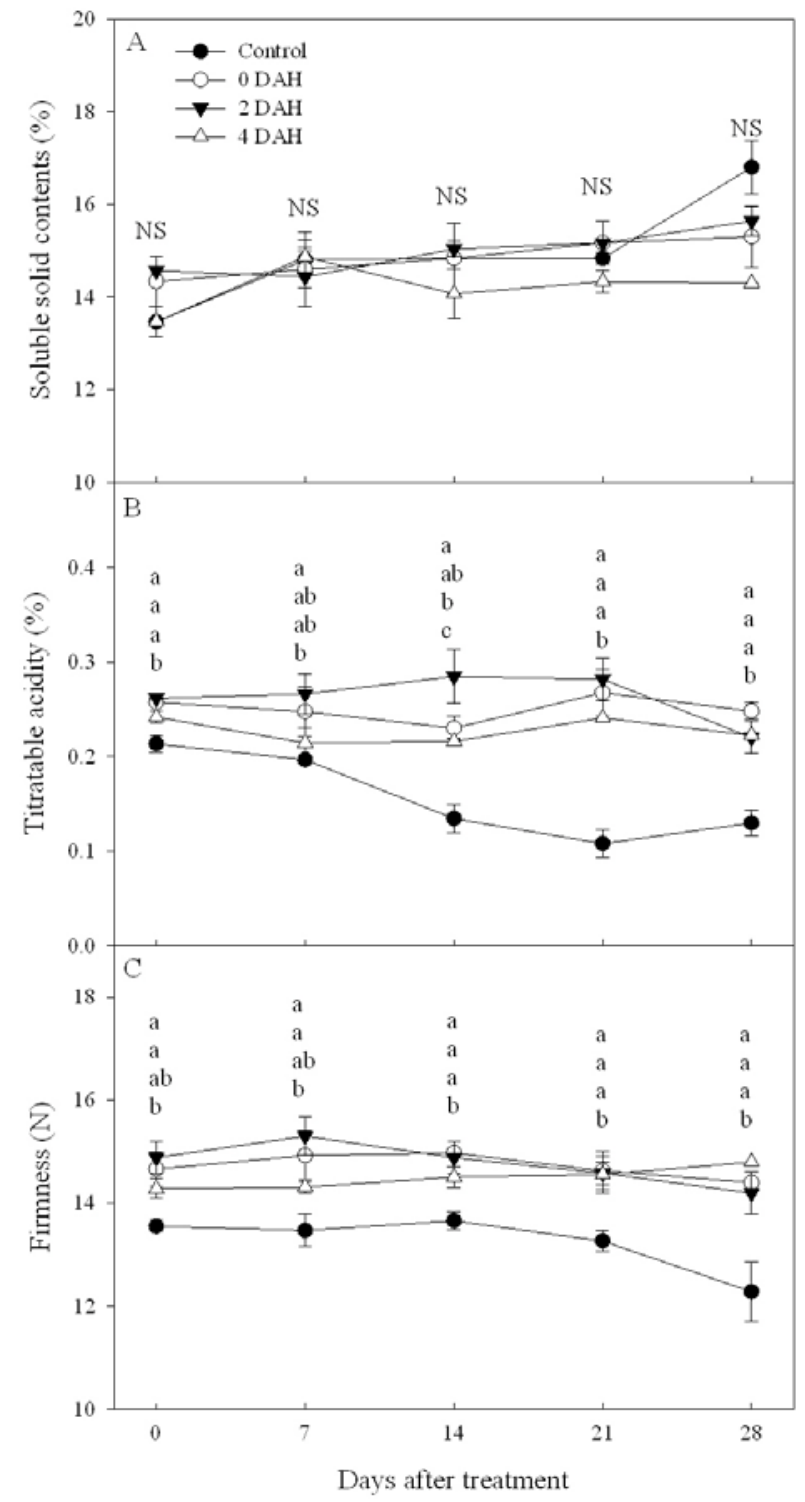

Figure 3. Soluble solid contents (SSC; A), titratable acidity (TA; B), and firmness (C) of 'Fuji' apple fruits untreated (control) or treated with $1,000 \mathrm{nl} \mathrm{l}^{-1} 1$-MCP of delays of 0,2 , and 4 days after harvest (DAH) at $20^{\circ} \mathrm{C}$ for $28 \mathrm{~d}$ after removal from $0.5^{\circ} \mathrm{C}$ cold storage for $180 \mathrm{~d}$. Bars represent error of the means (S.E.M; $n=10$ ), when larger than the dimension of the symbol. Different lower-case letters adjacent to each datum point at each sampling date indicate differences as determined by Duncan's MRT $(P \leq 0.05)$

The differences of SSC, TA, and firmness of the fruit in cold storage between the treatments were similarly observed at $20^{\circ} \mathrm{C}$ for $28 \mathrm{~d}$. Fruit SSC was not markedly affected by 1-MCP treatment time and control (Figure 3A). Loss of fruit TA was inhibited by 1-MCP treatments (Figure 3B) as reported in other 'Fuji' apples [6,8]. Fruit firmness was the lowest for control, having a low TA, with overall no difference observed for both TA and firmness between time of 1-MCP treatment (Figure 3C). High fruit TA resulted in firm fruit of various apple cultivars [13]. Lower ethylene concentration at harvest date of 'Fuji' apples would have less affected fruit TA or firmness, regardless of 1-MCP treatment time [14]. High ethylene concentration initiated at late harvested 'Empire' 
apples increased fruit softening in cold air plus shelf life with increasing storage periods, showing significant effects of 1-MCP treatment time up to $8 \mathrm{~d}$ after harvest [14]. This would be because late season of 'Fuji' cultivar has low initial ethylene concentration occurring at the harvest [18], catalyzing by 1-aminocyclopropane-1carboxylic acid (ACC) synthase and the ACC oxidase [19].

Prolonged-cold-stored 'Fuji' apples could be commercially transported for $28 \mathrm{~d}$ at room temperature when applied with $1,000 \mathrm{nl} \mathrm{l}^{-1} 1-\mathrm{MCP}$ within $4 \mathrm{~d}$ of harvest. The 1-MCP-treated fruits retained more than $14 \mathrm{~N}$ fruit firmness value (10\% reduction of initial firmness) during long-term storage, keeping shelf-life of fruit quality in Korean market. Flexibility of 1-MCP treatment time would provide a remarkable benefit for growers during the harvest season by maintaining good fruit quality. Further studies are required to evaluate the long-term responses to extended intervals of 1-MCP treatment from harvest on postharvest fruit quality.

\section{Acknowledgements}

This work was supported by research grants from the Catholic University of Daegu in Republic of Korea in 2014.

\section{References}

[1] Fan, X., Blankenship, S.M. and Mattheis, J.P, “1methylcyclopropene inhibits apple ripening," Journal of the American Society for Horticultural Science, 124. 690-695. 1999.

[2] Watkins, C.B, "Overview of 1-methylcyclopropene trials and uses for edible horticultural crops,” HortScience, 43. 86-94. 2008.

[3] Blankenship, S.M. and Dole, J.M, "1-methylcyclopropene: a review,” Postharvest Biology and Technology, 28. 1-25. 2003.

[4] Jung, S.K. and Watkins, C.B, "Superficial scald control after delayed treatment of apple fruit with diphenylamine (DPA) and 1methylcyclopropene (1-MCP)," Postharvest Biology and Technology, 50. 45-52. 2008.

[5] DeEll, J.R., Ayres, J.T. and Murr, D.P, “1-Methylcyclopropene concentration and timing of postharvest application alters the ripening of 'McIntosh' apples during storage," HortTechnology, 18. 624-630. 2008.

[6] Lim, B.S., Oh, S.Y., Lee, J.W. and Hwang, Y.S, "Influence of 1methylcyclopropene treatment time on the fruit quality in the 'Fuji' apple (Malus domestica)," Korean Journal of Horticultural Science \& Technology, 25. 191-195. 2007.

[7] Lu, X.G., Nock, J.F., Ma, Y.P., Liu, X.H. and Watkins, C.B, "Effects of repeated 1-methylcyclopropene (1-MCP) treatments on ripening and superficial scald of 'Cortland' and 'Delicious' apples,” Postharvest Biology and Technology, 78. 48-54. 2013.

[8] Tatsuki, M., Endo, A. and Ohkawa, H, "Influence of time from harvest to 1-MCP treatment on apple fruit quality and expression of genes for ethylene biosynthesis enzymes and ethylene receptors,” Postharvest Biology and Technology, 43. 28-35. 2007.

[9] KREI, Agricultural outlook 2008, Korea Rural Economic Institute Publishing, Seoul, Korea, 2008, 1-971.

[10] Jung, S.K., Choi, H.S. and Gu, M, "Effect of pre- and postload 1MCP on quality of 'Tsugaru' apples exposed to ethylene," Journal of Food Agriculture and Environment, 9. 214-218. 2011.

[11] Fawbush, F., Nock, J.F. and Watkins, C.B, "External carbon dioxide injury and 1-methylcyclopropene (1-MCP) in the 'Empire' apple,” Postharvest Biology and Technology, 48. 92-98. 2008.

[12] Watkins, C.B., Nock, J.F. and Whitaker, B.D, "Responses of early, mid and late season apple cultivars to postharvest application of 1methylcyclopropene (1-MCP) under air and controlled atmosphere storage conditions,” Postharvest Biology and Technology, 19. 1732. 2000.

[13] BAI, J., Baldwin, E.A., Goodner, K.L., Mattheis, J.P. and Brecht, J.K, "Response of four apple cultivars to 1-methylcyclopropene treatment and controlled atmosphere storage," HortScience, 40. 1534-1538. 2005.

[14] Watkins, C.B. and Nock, J.F, "Effects of delays between harvest and 1-methylcyclopropene treatment, on ripening of air-stored and controlled-atmosphere-stored apples,” HortScience, 40. 2096-2101. 2005.

[15] Blankenship, S.M. and Sisler, E.C, "Ethylene binding-site affinity in ripening apples," Journal of the American Society for Horticultural Science, 118. 609-612. 1993.

[16] Zhang, Z., Huber, D.J., Hurr, B.M. and Rao, J, "Delay of tomato fruit ripening in response to 1-methylcyclopropene is influenced by internal ethylene levels," Postharvest Biology and Technology, 54. 1-8. 2009.

[17] Sisler, E.C. and Serek, M, "Inhibitors of ethylene responses in plants at the receptor level: recent developments," Physiologia Plantarum, 100. 577-582. 1997.

[18] DeLong, J.M., Prange, R.K. and Harrison, P.A, "The influence of 1-methylcyclopropene on 'Cortland' and 'McIntosh' apple quality following long-term storage,” HortScience, 39. 1062-1065. 2004.

[19] Kende, H, "Ethylene biosynthesis," Annual Review of Plant Physiology, 44. 283-307. 1993. 